\title{
Assessment of Key HIV Misconceptions among Inhabitants of a Rural Community in Enugu State, Nigeria
}

\author{
Edmund 0. Ndibuagu ${ }^{*}$, Innocent I. Okafor ${ }^{2}$, Babatunde I. Omotowo ${ }^{3}$ \\ ${ }^{1}$ Department of Community Medicine and Primary Health Care, Enugu State University College of Medicine, \\ Enugu, Nigeria \\ ${ }^{2}$ Department of Obstetrics and Gynaecology, Enugu State University College of Medicine, Enugu, Nigeria \\ ${ }^{3}$ Department of Community Medicine, University of Nigeria College of Medicine, Enugu Campus, \\ Enugu, Nigeria \\ Email: * edmund.ndibuagu.esut.edu.ng
}

How to cite this paper: Ndibuagu, E.O., Okafor, I.I. and Omotowo, B.I. (2017) Assessment of Key HIV Misconceptions among Inhabitants of a Rural Community in Enugu State, Nigeria. Journal of Biosciences and Medicines, 5, 65-74.

https://doi.org/10.4236/jbm.2017.59007

Received: August 16, 2017

Accepted: September 16, 2017

Published: September 19, 2017

Copyright ( 2017 by authors and Scientific Research Publishing Inc. This work is licensed under the Creative Commons Attribution International License (CC BY 4.0).

http://creativecommons.org/licenses/by/4.0/

\begin{abstract}
In 2015, about 35 million people died of HIV infection globally, with about 36.7 million infected. Most of the infection occurred in Sub-Saharan Africa. Misconceptions about HIV/AIDS exist mostly in developing countries. The research was a cross-sectional study, conducted in Enugu state, Nigeria. Objective was to assess key HIV misconceptions among rural community dwellers. Interviewer administered questionnaire was used, and information was collected from 296 respondents, most of whom were above 50 years of age, married, had no formal education, and were farmers. Correct responses to the misconceptions investigated were: HIV infection found only among sinners (29.7\%); HIV can be transmitted by eating from the same plate with an infected person (24.7\%); HIV can be transmitted through handshake (29.7\%); HIV can be transmitted by touching the urine or faeces of an infected person (24.0\%); HIV can be transmitted by hugging or touching an infected person (28.0\%); HIV can be cured (19.9\%); Praying daily can prevent HIV infection (20.3\%); and Worshipping our ancestors can prevent HIV infection (27.0\%). Inhabitants of rural communities are more likely to hold misconceptions about HIV. It is recommended that relevant governments in developing countries design interventions aimed at addressing misconceptions about HIV/AIDS.
\end{abstract}

\section{Keywords}

Assessment, HIV, Misconceptions, Rural, Community 


\section{Introduction}

Acquired Immunodeficiency Syndrome (AIDS) was identified as a new disease among male homosexuals in California and New York areas of the United States of America in 1981 [1]. It is a later manifestation of infection with Human Immunodeficiency Virus (HIV). This virus attacks the immune system of the infected individual, making him/her more susceptible to opportunistic infections, and development of certain malignant diseases [2]. As at the end of 2015, more than 35 million people died of HIV infection globally, with about 36.7 million people still infected with the virus. Most of those infected with the virus are found in Sub-Saharan Africa (about 25.6 million people as at the end of 2015). Though HIV infection is still of great public health importance, it is however on the decline, recording about 35\% fall between 2000 and 2015 [3], and 43\% reduction in HIV related deaths since 2003 globally [4]. Though transmission of HIV was first recorded among homosexual men, infection is predominantly spread through the heterosexual route, and also through transfusion with infected blood, infected mother to the child, and infected needles/sharp objects [2].

Misconceptions about HIV/AIDS have been found mostly in developing countries, including Nigeria. Almost half of high school students that participated in an HIV/AIDS study in India erroneously believed that HIV infection can occur through sitting on a toilet seat used by an infected person [5]. Reasonable number of respondents from twelve villages in rural China believes that HIV infection can occur through swimming, speaking face-to-face with an infected person, shaking hands with an infected person, sharing meals with an infected person, and mosquito bite [6]. In a study conducted in Southwest Nigeria in 2009, over one third of respondents believed that HIV could be transmitted through mosquito bite, holding hands, talking to people with HIV, and hugging [7]. In another Nigeria study among pregnant women, as many as $15 \%$ of respondents believed that HIV/AIDS is curable. That same study found out that some of the respondents attributed the disease to punishment from God or witchcraft; while a few thought that sacrifice to the "gods" and herbs could prevent infection with HIV [8]. Some studies in Southern Ethiopia also revealed misconceptions about HIV [9]. Studies in Kenya and Ghana found that some people believe that HIV could be transmitted through touching an infected person, and mosquito bite [10] [11].

HIV infection is still a very significant public health problem in Nigeria, with the country being rated as having the second largest epidemic globally. It is however comforting to note that the prevalence has been on the decline recently, with current adult prevalence rate being 3.1\% [12].

Misconception about HIV, even among persons who were reported to have good knowledge of HIV/AIDS, still abounds [13]. This is worrisome since misconceptions of these types are associated with behaviours that are predisposed to HIV infection [14]. Correct knowledge about HIV is very crucial in controlling the spread of the infection [15]. Myths and misconceptions about the routes of 
HIV transmission still persist globally, though it is common in the developing countries. Global experience suggests that public knowledge on HIV is a crucial tool in the control of HIV/AIDS [16]. There is higher rate of HIV infection in rural areas in Nigeria [17]. It is therefore very important that the level of misconception in these rural areas is assessed, with the aim of identifying the gaps, and improving on them. The main objective of this study is to assess key HIV misconceptions among people living in a rural community of Enugu state, Southeast Nigeria.

\section{Materials and Methods}

Enugu State is one of the thirty six states that make up Nigeria. It is located in the Southeastern part of the country, and has seventeen Local Government Areas. This study was conducted in Egede town, a rural community in Udi Local Government Area of the State. The community is predominantly inhabited by farmers, petty traders, palm wine tappers, and hunters. Most of them were Christians, with very few being Traditional religion worshipers; while no inhabitant of the community practiced the Islamic religion. There are four Primary Schools and one Secondary school in the community, hence few teachers and reasonable number of school-aged children and teenagers also reside in the town. The study was of descriptive, cross sectional design, using pre-tested interviewer administered questionnaire. The questionnaire was completed during a medical outreach activity in January 2015, organized by indigenes of Udi Local Government Area who are health workers in the State University Teaching Hospital, Enugu. The questionnaire was administered by research assistants that were trained for this purpose. The aim of the research was adequately explained to the respondents, and all voluntarily gave their consent before being interviewed. Five junior resident doctors and ten medical students served as research assistants for this study. All persons aged 18 years and above, who presented for medical care during the Outreach activity were interviewed. A total of 296 copies of the questionnaire were completed and analyzed. During the same Outreach activity, information was also gathered for other studies on HIV/AIDS, diabetes mellitus, and malaria.

The information gathered from the interview was analyzed using SPSS version 20 , and presented in tables. The outcomes were measured in percentages, and figures less than $50 \%$ were considered poor.

\section{Results}

Socio-Demographic variables (Table 1): Majority of the respondents were above 50 years of age (77\%), while only $23 \%$ were below 50 years of age. Most were females $(69.9 \%)$, married (82.8\%), had no formal education $(52.7 \%)$, and farmers by profession (69.9\%).

Assessment of misconceptions about HIV/AIDS (Table 2): Most of the respondents were not sure whether HIV infects only sinners (57.8\%), while only 
Table 1. Socio-Demographic variables.

\begin{tabular}{|c|c|c|}
\hline Age range (in years) & Frequency $(\mathrm{N}=296)$ & Percent (100\%) \\
\hline$<19$ & 4 & 1.4 \\
\hline $20-29$ & 11 & 3.7 \\
\hline $30-39$ & 22 & 7.4 \\
\hline $40-49$ & 32 & 10.8 \\
\hline $50-59$ & 67 & 22.6 \\
\hline $60-69$ & 72 & 24.6 \\
\hline 70 and above & 88 & 29.7 \\
\hline \multicolumn{3}{|l|}{ Sex } \\
\hline Female & 207 & 69.9 \\
\hline Male & 89 & 30.1 \\
\hline \multicolumn{3}{|l|}{ Marital status } \\
\hline Married & 245 & 82.8 \\
\hline Single & 13 & 4.4 \\
\hline Divorced/Separated & 3 & 1.0 \\
\hline Widowed & 35 & 11.8 \\
\hline \multicolumn{3}{|l|}{ Educational Status } \\
\hline No formal Education & 156 & 52.7 \\
\hline Primary level & 89 & 30.1 \\
\hline Secondary level & 37 & 12.5 \\
\hline Tertiary level & 6 & 2.0 \\
\hline Postgraduate level & 8 & 2.7 \\
\hline \multicolumn{3}{|l|}{ Occupation } \\
\hline Farmer & 207 & 69.9 \\
\hline Petty trader & 38 & 12.8 \\
\hline Artisan & 16 & 5.4 \\
\hline Retired & 16 & 5.4 \\
\hline Civil servant & 12 & 4.1 \\
\hline Unemployed/student & 7 & 2.4 \\
\hline
\end{tabular}

29.7\% knew that this is not true. HIV being transmitted by eating from the same plate with an infected person was believed by $12.2 \%$ of respondents, while $24.7 \%$ knew it was false, and $63.2 \%$ were not sure. Handshake being a means of HIV transmission was reported by only $7.1 \%, 29.7 \%$ knew this is not true, while $63.2 \%$ are not sure. HIV being transmitted by touching the urine or faeces of an infected person was reported to be true by $13.2 \%, 24.0 \%$ correctly knew this was 
Table 2. Assessment of misconceptions about HIV/AIDS.

\begin{tabular}{lccc}
\hline \multicolumn{1}{c}{ Comment } & True (\%) & Not sure (\%) & False (\%) \\
\hline $\begin{array}{l}\text { It is found only among sinners } \\
\begin{array}{l}\text { HIV can be transmitted by eating from the } \\
\text { same plate with an infected person }\end{array}\end{array}$ & $36(12.5)$ & $171(57.8)$ & $88(29.7)$ \\
$\begin{array}{l}\text { HIV can be transmitted through handshake } \\
\text { HIV can be transmitted by touching the urine }\end{array}$ & $21(7.1)$ & $187(63.2)$ & $73(24.7)$ \\
$\begin{array}{l}\text { or faeces of an infected person } \\
\text { HIV can be transmitted by hugging or touching }\end{array}$ & $27(9.13 .2)$ & $186(62.8)$ & $71(24.0)$ \\
$\begin{array}{l}\text { an infected person } \\
\text { HIV can be cured }\end{array}$ & $54(18.2)$ & $183(62.8)$ & $83(28.0)$ \\
$\begin{array}{l}\text { Praying daily can prevent HIV infection } \\
\begin{array}{l}\text { Worshipping our ancestors can prevent HIV } \\
\text { infection }\end{array}\end{array}$ & $57(19.3)$ & $179(60.5)$ & $60(10.8)$ \\
\hline
\end{tabular}

false, while $62.8 \%$ were not sure. Hugging or touching an infected person being a route of HIV transmission was believed to be true by $9.1 \%$, with $28.0 \%$ disagreeing, and 62.8\% not being sure. Most of the respondents (61.8\%) were not sure whether HIV infection is curable. Few (19.9\%) knew that it is not curable, while $18.2 \%$ believed that it is curable. Most (60.5\%) were not sure whether HIV infection can be prevented by praying daily, $19.3 \%$ thought this is true, while $20.3 \%$ correctly knew that this is false. Again, many (62.2\%) were also not sure whether worshipping their ancestors prevents HIV infection; $27.0 \%$ knew that this was false, while $10.8 \%$ believed this was true.

\section{Discussion}

This study was conducted during a medical outreach programme in a rural community. The programme stretched for about nine hours, hence it was only the older members of the community who were mostly chronically ill, that had the patience to wait for medical attention. This resulted in $77 \%$ of our respondents being more than 50 years of age. The demographic pattern recorded in this study certainly did not represent the true picture in the community. It is culturally acceptable for women to report illnesses more frequently than men [18]. This probably explains why we had up to $69.9 \%$ of our respondents being women. In keeping with the typical picture seen in rural areas in Nigeria, most of the respondents did not have Primary education. Low level of education among inhabitants in the rural areas contributes to widespread misconceptions about HIV in those areas [9]. Majority of the respondents in this study, not having formal education (52.7\%) revealed that the literacy level is low. This possibly contributed to the level of misconception found in this study.

Some religious leaders believe that HIV is a punishment from God for people who commit sexual sin [19]. Only $29.7 \%$ of respondents knew that this is not correct. This has the potential of encouraging a large number of persons who 
ought to provide care and compassion for People Living with HIV, denying them the needed care. In addition to being punishment for evil committed in the past, some pregnant women in Nigeria also believe that witchcraft could cause HIV/AIDS [8]. There are widespread misconceptions in some rural areas about HIV transmission, with some believing that it can be transmitted through sharing food or drink, shaking hands, or being in the same room with an infected person [20]. Though only $12.2 \%$ of respondents believed that HIV can be transmitted by eating from the same plate used by an infected person, up to $63.2 \%$ of them not being sure whether this is possible is worrisome. Most people in that group may eventually be deceived into believing that HIV transmission can occur through sharing meal with an infected person. This eventually will increase the problem of stigmatization and militate against HIV/AIDS control efforts. It is a bit curious that in an HIV/AIDS study among secondary school students in Osun state, Nigeria six years ago; as high as $22.4 \%$ of the respondents believed that HIV transmission could occur through sharing meal with an infected person [21]. One would have expected that since the Osun state study was conducted among secondary school students who are more educated than most of the respondents in this study, knowledge that HIV is not transmitted through sharing of meals should have been better among them. Similar finding (26.5\%) to that of Osun state was made in rural China ten years ago [6], but a much higher level of misconception about eating and drinking as a route of HIV transmission (50.8\%)was documented among rural communities inhabitants in Sudan four years ago [22].

One obvious way of dramatizing stigmatization of HIV infected person is by avoiding a handshake with the person. This usually occurs in public and could be very embarrassing. Though the finding in this study, that only $7.1 \%$ of the respondents believed that HIV can be transmitted through handshake could be said to be encouraging; having up to $63.2 \%$ of them not being sure if transmission could occur through handshake is worrisome. The finding on misconception about handshake being a route of HIV transmission appears slightly better than the finding in the previously cited Osun state, Nigeria study where $10.5 \%$ of respondents believed that HIV can be transmitted by holding hands. The level of misconception found in this study, about handshake being a route for HIV transmission again appears better than the $24.6 \%$ found in rural China ten years ago [6]. This finding in China could have improved tremendously by now, since it is probable that more information on HIV transmission could have been made available to the rural population in China, in the last ten years. A more worrisome finding of $48.8 \%$ of respondents believing that transmission of HIV could occur through handshake was made four years ago in rural communities in $\mathrm{Su}$ dan [22].

If people who provide care for People Living with HIV (PLHIV) believe that touching the urine or faeces of infected persons could transmit the infection, they might be scared of assisting the very ill HIV/AIDS patients dispose their 
urine and faecal waste. This will adversely affect the care and support available to the PLHIVs and worsen their prognosis. Only $24.0 \%$ of respondents in this study knew that HIV infection cannot be contracted through touching urine or faeces of infected persons. This needs to be improved upon.

Another common misconception about HIV/AIDS is that transmission can occur through hugging or touching an infected person. As high as $33.2 \%$ of respondents in a study among rural adult population in Southwestern Nigeria, eight years ago believed that HIV transmission could occur through hugging, talking to people infected with HIV, and holding their hands [7]. A more encouraging finding of $16.2 \%$ was made in March this year among secondary school students in another Southwestern state of Nigeria [21]. An apparently better finding of only $9.1 \%$ of respondents having that misconception was made in this study. The limitation of this finding is that only $28.0 \%$ of respondents are certain that hugging or touching an infected person does not transmit HIV. As high as $62.8 \%$ were not sure if HIV infection could occur through hugging or touching an infected person. HIV/AIDS currently not having a cure is very vital information that could serve as a deterrent to irresponsible behaviours that expose people to HIV infection. It is very worrisome that only $19.9 \%$ of respondents in this study had this knowledge. Many pregnant women (58.6\%) in Gwagwalada Area Council of Abuja, Nigeria had the correct knowledge two years ago, that currently there is no cure for HIV/AIDS [8]. This could be because Abuja is an urban area, and pregnant women are usually given health talk during their antenatal visits. These probably accounted for the better knowledge exhibited by respondents in the Gwagwalada Abuja study. Another study in Nigeria revealed that $29.4 \%$ of respondents believed that there is cure for HIV/AIDS [21]. A slightly better finding of $18.2 \%$ in this study could again be apparent, since most of the respondents were not sure if HIV/AIDS was curable or not. Some people, including certain most at risk persons believe that praying daily could protect them from HIV infection even in the face of having unprotected sexual intercourse. In a qualitative study among Female Commercial Sex Workers done in four cities in Nigeria, almost all of them are aware of the risk of HIV infection when having unprotected sexual intercourse, but many expose themselves to that risk after praying and believing that all merciful and forgiving God will protect them [23]. Only $20.3 \%$ of respondents in this study knew that only prayers do not protect from HIV infection. This implies that most of them could be careless with their sexual life, believing that only daily prayers offer protection against HIV infection. Better knowledge on "Worshipping our ancestors as a method of HIV prevention" was demonstrated by respondents in this study, than was found in their using prayers as HIV preventive method. This probably is because most of them are Christians. In the already cited Gwagwalada, Abuja, Nigerian study, few of the respondents believed that sacrifices to the "gods" prevent HIV infection [8]. It was however documented in a South African qualitative study among youths, that traditional ancestral worship significantly influ- 
enced people's response to HIV/AIDS [24].

In a study conducted at the same time, and among the same respondents, some misconceptions about routes of HIV transmission were documented as follows; inhaling polluted air (79.1\%), drinking water touched by HIV infected person (74.3\%), and insect bite (77.7\%) [25]. Considering only the data on the number of respondents that answered "TRUE" to the questions asked on misconception, one will get the erroneous impression that the level of misconception in the community is low. However, when one considers that also very few respondents are certain about those comments being misconceptions, and that majority are not sure, then it becomes obvious that so much misconceptions about HIV/AIDS abound in the rural community where this study was conducted. Looking at the results obtained during a concurrent research among the same respondents [25], confirms this. Probably not giving the respondents the option of "NOT SURE" would have made them clearly take a stand.

\section{Conclusion}

Misconceptions about HIV/AIDS could usually be associated with different risky behaviours that might lead to getting infected with HIV [10] [14]. Misconception has the potential of preventing people from taking necessary steps aimed at preventing HIV infection [26]. In keeping with findings in some rural communities in Africa [9], there is worrisome level of misconceptions about HIV/AIDS among inhabitants of rural population in our study. Since inhabitants of rural communities probably are more likely to hold misconceptions about HIV [27], it is very crucial that relevant governments in developing countries design interventions aimed at addressing these misconceptions and empowering the rural dwellers with adequate information on HIV/AIDS. This will greatly enhance the adoption of behaviour change in these rural communities, and contribute positively to HIV control efforts.

\section{References}

[1] Hymes, K.B., Cheung, T., Green, J.B., Prose, N.S., Marcus, A., Ballard, H., William, D.C. and Laubenstein, L.T. (1981) Kaposis Sarcoma in Homosexual Men: A Report of Eight Cases. The Lancet, 2, 598-600. https://doi.org/10.1016/S0140-6736(81)92740-9

[2] Park, K. (2013) Parks Textbook of Preventive and Social Medicine. 21st Edition, $\mathrm{M} / \mathrm{s}$ Banarsidas Bhanot Publishers, Jabalpur.

[3] WHO. (2016) HIV/AIDS Fact Sheet. http://www.who.int/mediacentre/factsheets/fs360/en

[4] WHO. (2016) Global Health Sector Strategy on HIV, 2016-2021. Towards Ending AIDS. http://apps.who.int/iris/bitstream/10665/44606/1/9789241501651_eng.pdf

[5] Kumar, P., Pore, P. and Partil, U. (2012) HIV/AIDS-Related KAP among High School Students of Municipal Corporation School in Pune: An International Study. National Journal of Community Medicine, 3, 74-79.

[6] Qian, H.Z., Wang, N., Dong, S., Chen, H., Zhang, Y., Chamot, E., Shi, X., Gao, J., 
Vermund, S.H. and Shao, Y. (2007) Association of Misconceptions about HIV Transmission and Discriminatory Attitudes in Rural China. AIDS Care, 19, 1283-1287. https://doi.org/10.1080/09540120701402814

[7] Asekun-Olarinmoye, E.O., Bamidele, J.O., Olowu, A.O., Odu, O.O., Egbewale, B.E. and Amusan, O.A. (2009) Sexual Risk Behaviours and Risk Perception of HIV/AIDS among a Rural Adult Population in Southwestern Nigeria. Journal of Research in Medical Sciences, 3, 80-86.

[8] Otokpa, A.O., Lawoyin, T.O. and Asuzu, M.C. (2015) Knowledge on HIV/AIDS and Sexual Risk Behaviour among Pregnant Women in Gwagwalada Area Council of Abuja, Nigeria. World Journal of Preventive Medicine, 3, 73-83.

[9] Asefa, A. and Beyene, H. (2013) Awareness and Knowledge on Timing of Mother-to-Child Transmission of HIV among Antenatal Care Attending Women in Southern Ethiopia: A Cross Sectional Study. Reproductive Health, 10, 66. https://doi.org/10.1186/1742-4755-10-66

[10] Tenkorang, E.Y. (2013) Myths and Misconceptions about HIV Transmission in Ghana: What Are the Drivers? Culture Health \& Sexuality, 15, 296-310. https://doi.org/10.1080/13691058.2012.752107

[11] Bernadi, L. (2002) Determinants of Individual AIDS Risk Perception: Knowledge Behavioural Control and Social Influence. African Journal of AIDS Research, 1, 111-124.

[12] National Agency for Control of AIDS (2015) Global AIDS Response. Country Progress Report, Federal Ministry of Health, Nigeria.

[13] Letamo, G. (2007) Misconceptions about HIV Prevention and Transmission in Botswana. African Journal of AIDS Research, 6, 193-198. https://doi.org/10.2989/16085900709490414

[14] Amoyaw, J.A., Kuuire, V.Z., Boateng, G.O., Asare-Bediako, Y. and Ung, M. (2015) Conundrum of Sexual Decision Making in Marital Relationships: Safer-Sex Knowledge, Behaviour, and Attitudes of Married Women in Zambia. The Journal of Sex Research, 52, 868-877. https://doi.org/10.1080/00224499.2014.996280

[15] UNICEF (2009) Newsletter, UNICEF Bangladesh, Issue 11.

[16] UNAIDS (2002) HIV/AIDS: China's Titanic Peril. 2001 Update of the AIDS Situation and Needs Assessment Report. UNAIDS China Office.

[17] National Agency for Control of AIDS (2015) Federal Ministry of Health, Abuja.

[18] Aniebue, N. (2008) Introduction to Medical Sociology. Institute for Development Studies, University of Nigeria, Enugu Campus.

[19] Kopelman, L.M. (2002) If HIV/AIDS Is Punishment, Who Is Bad? The Journal of Medicine and Philosophy, 27, 231-243. https://doi.org/10.1076/jmep.27.2.231.2987

[20] Irwin, K., Bertrand, J., Mibandumba, N., Mbuyi, K., Muremeri, C, Mukoka, M., Munkolenkole, K., Nzilambi, N., Bosenge, N., Ryder, R., Peterson H., Lee, N.C., Wingo, P., O’Reilly, K. and Rufo, K. (1991) Knowledge, Attitudes and Beliefs about HIV Infection and AIDS among Healthy Factory Workers and Their Wives, Kinshasa, Zaire. Social Science and Medicine, 32, 917-930.

[21] Bamise, O.F., Bamise, C.T. and Adedigba, M.A. (2011) Knowledge of HIV/AIDS among Secondary School Adolescents in Osun State, Nigeria. Nigeria Journal of Clinical Practice, 14, 338-344. https://doi.org/10.4103/1119-3077.86780

[22] Khamis, A.H. (2013) HIV and AIDS Related Knowledge, Beliefs and Attitudes among Rural Communities Hard to Reach in Sudan. Health, 5, 1494-1501.

https://doi.org/10.4236/health.2013.59203 
[23] Akinyemi, Z., Ankomah, A., Ladipo, O. and Anyanti, J. (2002) Perceived Faith-Based Invulnerability to HIV Infection among Female Sex Workers in Nigeria. XIV International AIDS Conference, Barcelona, 7-12 July 2002.

http://www.sfhnigeria.org/

[24] Siwela, M. and Jansen, C. (2016) Conflicting Voices in HIV/AIDS Education of the South African Youth: School Culture versus South African Traditional Healers using Ancestral Worship. International Journal of Criminology and Sociology, 5, 123-142. https://doi.org/10.6000/1929-4409.2016.05.12

[25] Ndibuagu, E.O., Arinze-Onyia, S.U. and Onoh, L.U. (2017) Knowledge of Causes, and Routes of Transmission of HIV/AIDS among Residents of a Rural Community in Enugu State, Southeast Nigeria. Medico Research Chronicles, 4, 221-229.

[26] Agyemang, S., Buor, D. and Tagoe-Darko, E. (2012) The Extent of Knowledge about HIV/AIDS among Young People in the Ejura-Sekyedumase District of Ghana. Journal of AIDS and HIV Research, 4, 241-247.

https://doi.org/10.5897/JAHR12.023

[27] Sano, Y., Antabe, R., Atuoye, K.N., Hussey, L.K., Bayne, J., Galaa, S.Z., Mkandawire, P. and Lugina, I. (2016) Persistent Misconceptions about HIV Transmission among Males and Females in Malawi. BMC International Health and Human Rights, 16, 16. https://doi.org/10.1186/s12914-016-0089-8

\section{Scientific Research Publishing}

\section{Submit or recommend next manuscript to SCIRP and we will provide best} service for you:

Accepting pre-submission inquiries through Email, Facebook, LinkedIn, Twitter, etc. A wide selection of journals (inclusive of 9 subjects, more than 200 journals)

Providing 24-hour high-quality service

User-friendly online submission system

Fair and swift peer-review system

Efficient typesetting and proofreading procedure

Display of the result of downloads and visits, as well as the number of cited articles

Maximum dissemination of your research work

Submit your manuscript at: http://papersubmission.scirp.org/

Or contact jbm@scirp.org 